\title{
Local Planning Practice towards Resilience: Insights from the Adaptive Co-Management and Design of a Mediterranean Wetland
}

\author{
Emma Salizzoni ${ }^{1, *}$, Rocío Pérez-Campaña ${ }^{2}$, Fernando Alcalde-Rodríguez ${ }^{3}$ and \\ Ruben Talavera-Garcia ${ }^{2}$ (D) \\ 1 Dipartimento Interateneo di Scienze, Progetto e Politiche del Territorio, Politecnico di Torino, \\ 10125 Torino, Italy \\ 2 Departamento de Geografía, Universidad Complutense de Madrid, 28040 Madrid, Spain; \\ r.perez.campana@ucm.es (R.P.-C.); rtalaveragarcia@ucm.es (R.T.-G.) \\ 3 Buxus, 18600 Motril, Spain; buxusasociacion@gmail.com \\ * Correspondence: emma.salizzoni@polito.it
}

Received: 31 January 2020; Accepted: 31 March 2020; Published: 5 April 2020

\begin{abstract}
Although widely, as well as recently explored, the concept of urban resilience still poses important issues in terms of its operationalization. For this reason, best practices that show how the resilience concept has been turned into planning practice are much needed. This article presents and discusses the case study of the Charca de Suárez Nature Concerted Reserve, an urban wetland situated along the Andalusian coast (Spain), to contribute to filling the gap on the operationalization of urban resilience at the local planning level. In the Charca, an adaptive co-management and design approach has been successfully put into practice to foster local urban resilience. Starting from some recent key studies on planning and management policies for urban resilience, we propose a framework to read, understand and evaluate the Charca experience, and more generally, resilience-based projects. The analysis highlighted the following crucial key aspects for urban resilience in the Charca case study: A collaborative governance model; and the building of community-capitals. The Charca de Suárez Nature Concerted Reserve can actually be acknowledged as an innovative planning practice, a source of inspiration for visions and experiments oriented to urban resilience.
\end{abstract}

Keywords: urban resilience; wetlands; adaptive co-management approach; planning policies

\section{Introduction}

The resilience paradigm has gained huge academic attention over the last years in a wide range of disciplines. In the context of urban studies and planning, urban resilience may be defined as the ability of complex socio-ecological systems to persist, adapt and transform in response to a wide variety of stresses (for a review of the concept, see Meerow et al. [1]). In urban planning, the rapid rise of the resilience concept has been paired with the uncertainty on how it should be operationalized [2,3], which explains why resilience remains greatly unpracticed in contemporary urban planning and design [4]. However, at present, the extensive discussion on the concept itself and its meaning in urban planning seems to have reached some agreed milestones that we can consider as starting points to advance towards its operationalization within planning:

(1) The need for a non-equilibrium and evolutionary approach;

(2) The need for an adaptive co-management and design approach;

(3) The crucial role played by green infrastructures and nature-based solutions; 
(4) The contribution made from case studies to elucidate the complex processes involved in resilience implementation within planning practice, with special attention to the local scale.

The first milestone corresponds to the wide acceptance on the need of a non-equilibrium approach, that means an understanding in terms of non-equilibrium of both the natural and built environments [5]. As Picket et al. [6] state, the focus is not on reaching or maintaining a certain endpoint or a terminal condition, but on staying "in the game" without modifying the basic state of a given system [7], or altering its essential characteristics [8]. The essence of resilience is, thus, to embrace change [9]. The intrinsic changing and non-linear nature of social-ecological systems in time and space $[3,10]$ implies the existence of multiple pathways towards resilience, as a continuum from persistence to transformation [1]. Thus, it is clear that there is no a "definite strategy" for resilience, but a transitioning to resilience [11] that implies multiple strategies in time and space in an evolutionary resilience framework [12].

Here it comes the second milestone. To cope with the uncertainty of social-ecological systems [13], and the complex, dynamic and non-linear human-nature relations [14], there is a wide consensus about the need for an adaptive co-management approach. Adaptive co-management combines the dynamic learning aspect of adaptive management with the vertical and horizontal linking aspect of collaborative management $[13,15]$. It is considered as an important approach for operationalizing urban resilience by building a flexible community-based governance system [16]. Adaptive co-management approach emphasizes pluralism and communication; shared decision-making and authority; linkages within and among levels; actor autonomy; and learning and adaptation [13]. This approach is gaining increasing attention as the management paradigm fails to perform efficiently when dealing with uncertainty, complexity, plural objectives and competing values [17].

The third milestone concerns the role of green infrastructures and nature-based solutions to foster urban resilience. Urban green space policy is increasingly being used as a tool to enhance urban resilience [11]. Blue-green infrastructures, in particular, are shown as tools to enhance multiple aspects of resilience [18], and nature-based solutions are considered as crucial elements of an ecosystem-based approach that directly addresses and contributes to urban resilience $[19,20]$.

The fourth and final milestone is the need for specific case studies that allow shifting from picture to real display of resilience implementation into planning practice. In other words, case studies and experiments may deliver tangible contributions to the transition to urban resilience [21]. Furthermore, the "learning-by-doing" approach [22] that is inherent to resilient thinking through adaptive co-management is not possible without "done" projects, which allow learning from their experience. Coafee et al. [23] state the interest of analyzing in-depth case studies in which the evolution of resilience from idea-to action-to results constitutes a mean to elucidate the complex process involved in resilience implementation. Case studies are also the only way of appreciating the existence of "negotiated resilience" [24] which refers to the ethical considerations in the continuous engaging process where diverse actors negotiate the resilience objectives and strategies. We also argue that case studies at the local scale are of special interest, since localities are the spaces of people's everyday lives, where experiential knowledge and face-to-face transactions take place [25].

All the mentioned milestones emerge in the literature as closely linked to the idea of "innovative planning". Friedmann [25] defined "innovative planning" as planning that looks forward creative solutions to the social, physical, and environmental problems that rise to political consciousness in the public domain. The challenges of sustainability and resilience demand innovation and experimentation [26,27].

Considering all the above-mentioned points, this research aims to contribute to filling in the gap of the operationalization of urban resilience at the local planning level. The experience of a small urban Mediterranean wetland (the Charca de Suárez Nature Concerted Reserve), namely, a blue-green infrastructure, is here analyzed to highlight the strategies implemented for building urban resilience, with a specific focus on adaptive co-management strategies. The results show that 
the Charca project can be considered as an innovative and successful planning practice that actually fosters local urban resilience.

\section{Materials and Methods}

\subsection{Territorial, Urban and Planning Context of the Case Study}

Some specific characteristics make the case study a very particular, but appropriate planning-for-resilience experiment:

- Small wetland: The Charca de Suárez area is just 14 ha. Small wetlands tend to be overlooked, and there are few works which analyse their specificities. Being small normally implies that there is no exploitation of wetland products (agriculture/aquaculture), as it is the case of the Charca. Manuel [28] states that it is quite easy to appreciate the different values of large and productive wetlands, but "it is quite another matter to understand the value of a small, reedy, pond tucked between a shopping mall parking lot and a row of well-manicured suburban backyards". It is not by chance that the existing guidelines and good practices are more commonly found for extensive wetlands.

- Isolated wetland: Although the Charca de Suárez was once a part of the Guadalfeo's Wetlands, now it is an isolated wetland, the only one in the Province of Granada. That prevents the regional approach that is normally agreed to be an optimal scale for wetland management $[29,30]$. Nevertheless, its isolated nature and the adverse conditions the Charca has gone through (see following paragraphs) have constituted the "crisis or changing context" from which the adaptive co-management normally emerges [31].

- Urban wetland: As mentioned in the introduction, the Charca is an urban wetland. Being urban also implies a specific reference domain separate from non-urban wetlands [32]. Even if the existing global wetlands policy directives are less optimal for effective governance in the case of urban wetlands [33], urban wetlands may be considered smart, cost-effective tools for urban designers and planners to be used in urban areas [34].

The Charca is located on the Mediterranean Coast, in the Municipality of Motril (Province of Granada) in the Andalusian Region (Spain) (Figure 1). Although the Charca is not included in the Ramsar List, the Charca may be classified as a "Marine/Coastal Wetland: Coastal freshwater lagoons; includes freshwater delta lagoons".

The Charca is one of the remaining wetlands in the delta of the Guadalfeo River. This area originated from the progressive accumulation of the sediments carried by the Guadalfeo River in a millennial process, when the river tended to overflow and formed a braided stream. This condition, together with the presence of a detritic aquifer with high ground-water level, determined the appearance of marshy areas. On the other hand, some mountain chains that run parallelly to the coastline (mainly Sierra Nevada) protect this area from cold northern winds and contribute to set a subtropical climate that is unique in Europe [35]. All these conditions allowed the introduction of sugar cane by the Arabs in the 10th century. A dense irrigation network was needed to maintain the high demand for water from sugar cane. This irrigation network, formed by traditional open ditches ("acequias", in its Spanish noun derived from Arab "as-Saqyha"), allowed water circulation on the surface, the water infiltration to the aquifer and contributed to the sediment deposition. During the 1940s, the Guadalfeo River was channeled, and different processes of drainage were implemented so that the wetlands in the delta were strongly reduced. In addition, in the last years of the XX Century, the sugar cane crop gradually disappeared, due to its low profitability (compared to greenhouses, for example) and the urban pressure, the European Union abolished the subsidy for the sugar cane in 2006. That came with a deep transformation in the Delta del Guadalfeo, that witnessed great agricultural land-use changes, intense urban development (especially since the first years of the present century [36]), and the increase of greenhouses between last 90s and mid-2000s [37]. The historical acequias network has 
also transformed and has been canalized or removed in some parts. Today, agricultural crops, such as avocado, citrus fruits, custard apple and vegetables coexist with greenhouses, industrial and urban areas and abandoned plots. The Charca de Suárez wetland has survived to this turn of events, and it is today one of the few remnant wetlands of the Guadalfeo (Figure 2).

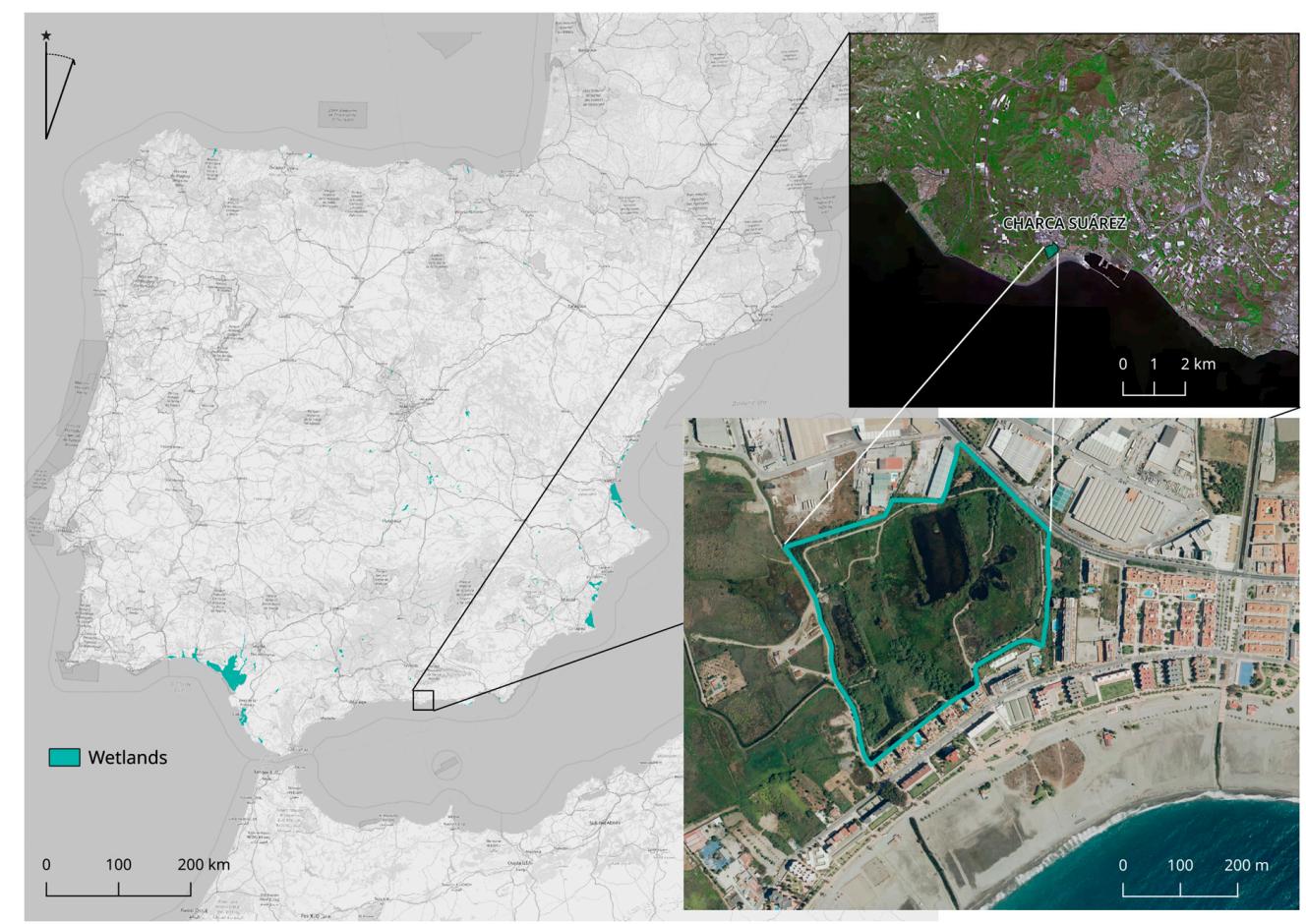

Figure 1. Location of the Charca de Suárez. Source: Authors.
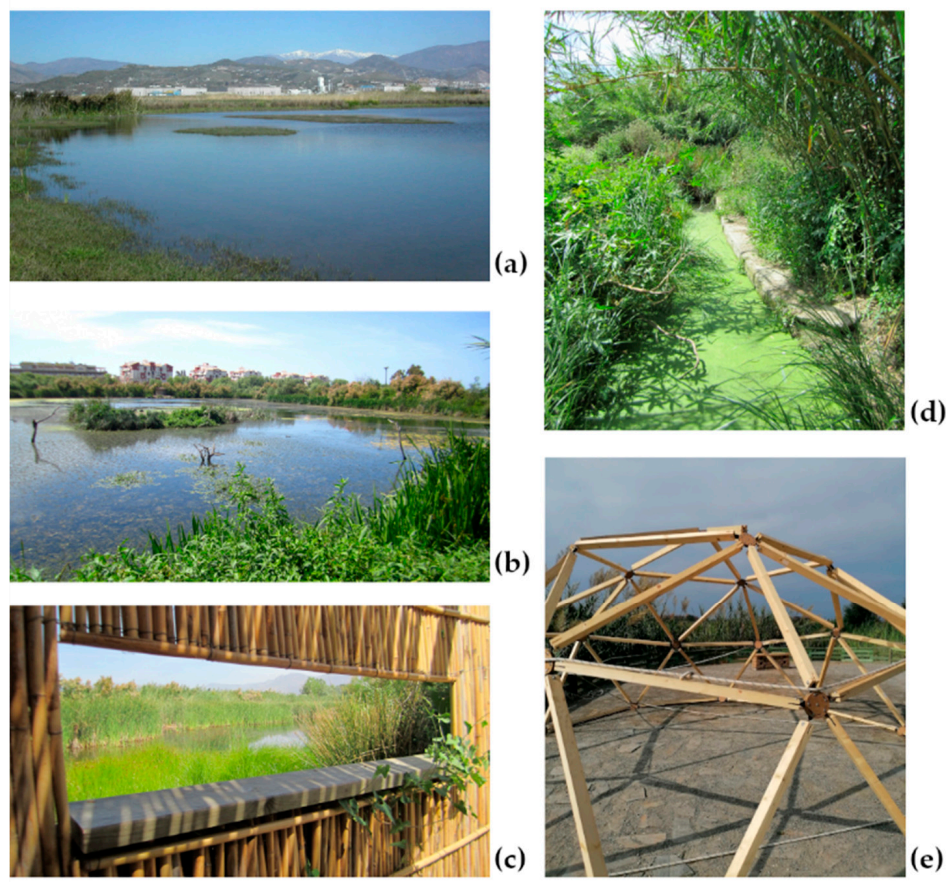

Figure 2. Charca de Suárez. (a) Charca de Suárez with Sierra Nevada National Park in the background, (b) views of the near urban settlements, (c) Charca de Suárez from a bird hide, (d) a ditch (acequia), (e) a structure for a bird hide designed and built in the context of the recent project "Arquitectura Descalza", a collaborative program implemented with the University of Málaga. Source: Authors. 
This socio-ecological construction process together with the biodiversity values of the Charca were the main arguments to declare the Charca as a "Nature Concerted Reserve" (NCR) in 2009. NCR is an innovative protection figure (it does not exist at the national level) contemplated in the Andalusian Law on Protected Natural Spaces. Through this figure, the landowners may take the initiative to apply a concerted protection regime to areas that may deserve specific protection. Nature Concerted Reserves are, thus, of local competence, but the Regional Government must inform positively and takes part in the concerted regime. The steps in the process to get this protection regime are important to understand the background of this successful case on the light of the resilience approach (Figure 3).

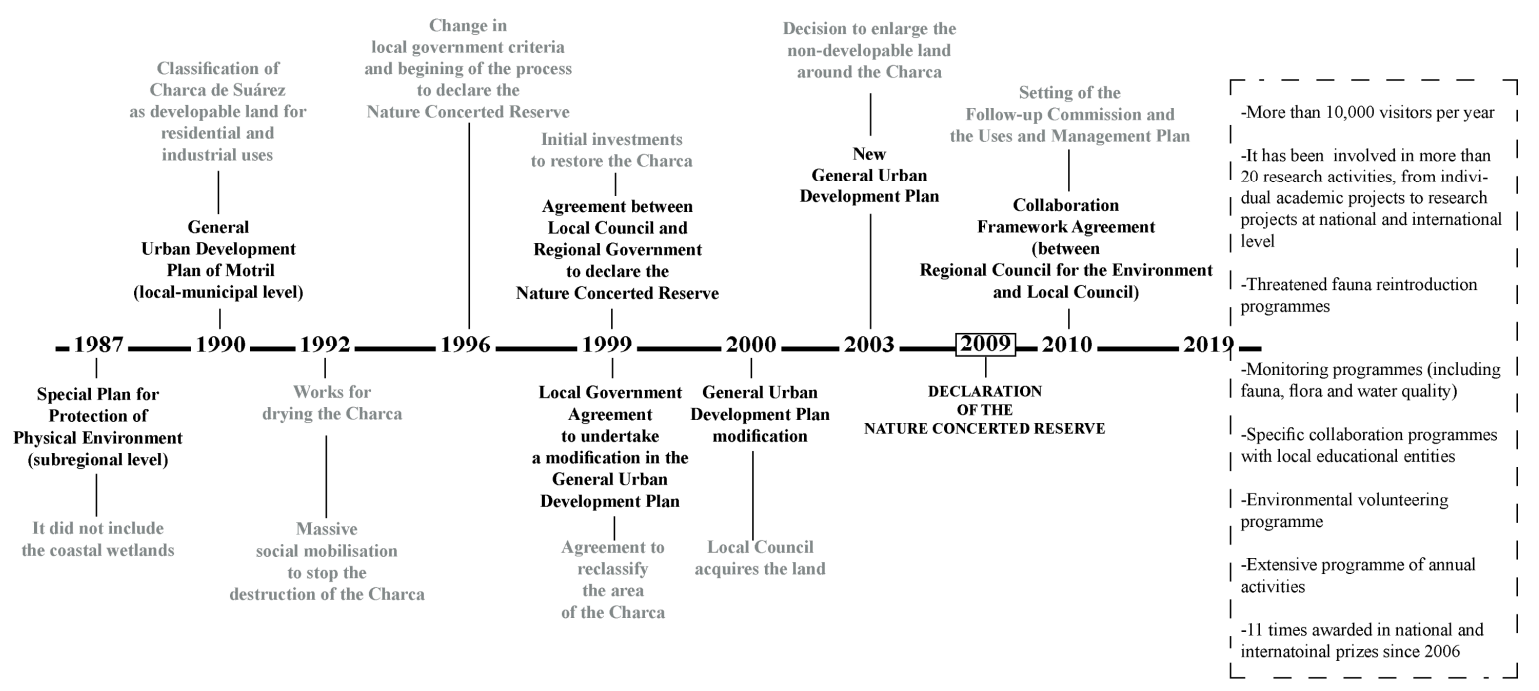

Figure 3. Timeline with the main phases of the planning and social context of the Charca. Source: Authors.

In 1987, the Regional Government of Andalucía approved the Special Plans for the Protection of the Physical Environment of Granada. This Plan aimed at protecting the main environmental values and giving indications to urban (local) plans about those areas that should be preserved and not included in urbanization processes. The Special Plan of Granada did not include the Charca de Suárez, and consequently, the 1990 General Urban Plan of Motril classified the Charca and the surrounding area to be urbanized for residential and industrial uses. As part of the urbanization process, the Local Council of Motril (the municipality) initiated the drying of the Charca in 1992, but a great social protest emerged from the local community and managed to stop the drying process. As in Olsson et al. [38], we can, thus, identify the circumstances that have helped open a "window of opportunity" for the Charca:

- A change in the Spanish policies that define the use and management of wetlands in the late eighties. According to Sebastià-Frasquet et al. [29], the period of 1950-1980 was characterized by plans promoting the filling and draining of wetlands for agricultural use, but with the incorporation of Spain to the European Union in 1986, there was a shift in these policies towards the inclusion of restoration and protection of wetlands. Nevertheless, the echoes of this first period maybe explain why the Special Plan for the Protection of the Physical Environment did not include coastal wetlands;

- The approval of the Law on Protected Natural Spaces of Andalusia in 1989, which contains the novel figure of Nature Concerted Reserve. This figure opened a possibility for the Charca de Suárez that was immediately explored by the actors involved in the Charca project; 
- The start of draining works of the Charca in 1992, which triggered a massive social response that was accompanied by an awareness campaign conducted by Buxus Ecologist Association (Asociación Buxus de Ecologistas en Acción), an environmental non-governmental organization.

The latter was the starting point for a debate between the population and the administrative bodies that ended up with a first agreement (in 1996) to work towards effective protection of the Charca as NCR. An official agreement between the Local Council of Motril and the Regional Government of Andalucía was signed in 1999, which was accompanied by the budget allocation of 180,000 $€$ on the part of the Regional Government (aimed at providing some facilities to the Charca) and the commitment of the municipality to modify the General Urban Plan of Motril. Once this modification was approved in 2000, the City Council acquired the land, thus, becoming both the landowner of the Charca with its surrounding area and a legitimate agent to promote the protection of the Charca as NCR. Still, in 2001, the Charca experienced some land-use change processes, discharges, and residential and industrial constructions around, provoking the partial draining of the wetland. However, in 2002 and 2006, different restoration works were undertaken before its declaration as NCR in 2009. After the declaration, a collaboration framework agreement was signed in 2010 by the Regional Council for the Environment and the Local Council of Motril to set up the protection regime and the uses allowed in the NCR. Two decisive instruments were envisaged in that document: The Follow-up Mixed Commission and the Uses and Management Plan. None of these instruments is mandatory for the case of Nature Concerted Reserves according to the Andalusian Law on Protected Natural Spaces. The Follow-up Mixed Commission was set in 2010. The Commission, working with a rotating presidency, is composed of six members: Three from the Regional Government and three from the local realm. Among the latter three, two belong to the Local Council and one to local people, who organize through the above-mentioned Buxus Ecologist Association. The Use and Management Plan of the Charca de Suárez Nature Concerted Reserve, approved in 2010, presents several, different and interrelated objectives. Beyond "Biodiversity conservation" and the "Preservation of local cultural values", an important set of objectives is dedicated to scientific, social and educational issues ("Enhancement of knowledge and research", "Sensitization and environmental education", "Dissemination"), as well as to the incrementing the tourist attractiveness ("Tourism and leisure") and the monitoring of the environmental quality and the Plan Implementation itself ("Control and maintenance", "Monitoring of the plan"). Thus, the Plan includes a wide array of aims, entailing both material and immaterial actions, with a strong focus on the integration between conservation and educational/recreation objectives and on policy effectiveness.

\subsection{A framework for Reading the Charca Experience in a Resilience Perspective}

Before going through the reading of the Charca case study, it is worth mentioning that the general information presented in this article has been obtained from the following main sources:

- The Charca de Suárez website (Local Council of Motril);

- The Visitor's Window to Protected Natural Spaces;

- The Uses and Management Plan of the Charca (available at the Local Council of Motril);

- Interviews with representatives of the Buxus Environmental Association and the Environment Area of the Local Council of Motril. The interviews implied questions mainly concerning management and planning policies adopted in the Charca and governance aspects (the Charca collaborative and supportive network, in particular, see Section 3);

- Field visits organized in different seasons between 2018 and 2019 to check landscape evolution and species' dynamic. 
The cartographic materials have been obtained from REDIAM (the Environmental Information Network of Andalusia). Information about the Motril General Urban Development Plan has been accessed through the Repository on Spatial and Urban Plans of Andalusia and also at the specific site of the Local Council of Motril. The official Declaration of the Nature Concerted Reserve of the Charca de Suárez has been accessed through the Official Gazette of the Andalusian Regional Executive.

All data derived from these different sources were read in an integrated way to support the case study analysis.

To evaluate the Charca project from the viewpoint of its innovative contribution to urban resilience within the context of local urban planning, we have followed and applied the theoretical frameworks provided by References [3,39] (general strategies for urban resilience) and [21] (focus on adaptive co-management and design strategies). The cross-referenced reading of these two approaches provided an optimal methodological base to read, evaluate and understand the Charca case study, and more generally, resilience-based projects. The two approaches together provide a comprehensive framework that meets the most consistent and agreed on insights on resilience within the context of urban planning policy and practice.

In respect of the strategies for building urban resilience, Ahern $[3,39]$ provides the following:

1. Multifunctionality. It implies how urban planning may contribute to providing multiple ecosystem functions in urban lands [39].

2. Redundancy and modularization. A modular and decentralized approach to avoid putting "all your eggs in one basket" [9].

3. Bio and social diversity. Both types of diversity are closely related to social-ecological systems. The more different biological and social groups we found in a system, the better, since all together may provide a wider range of responses to the changing conditions of the environment.

4. Multi-scale networks and connectivity. Urban landscapes should be understood as multi-scale network systems that perform different functions thanks to their connectivity [3].

5. Adaptive planning and design. It implies the performance of planning and design in a context of uncertainty and incomplete knowledge [39].

We then focused on the latter point, namely, the adaptive planning and design policies, and we enriched its interpretation through the "co-management" dimension. To analyze this point, we referred to Crowe et al. [21], who define a strategical framework for adaptive co-management strategies that include the following three components and their corresponding key aspects:

1. Understanding the system. It includes, as key aspects: Active observation, accessible information, identification of drivers of change, and broader value systems.

2. Operating within the system. It includes, as key aspects: less-hierarchical approaches, collaborative and supportive networks, build community capital, and incremental and experimental approach.

3. Efficient resource management. It includes, as key aspects: Build local awareness; connect resources, people, and places, use what exists optimally, and design for change.

Considering the two previous approaches to understand resilience in urban planning, we can evaluate the specificities of a given project (see Figure 4). This evaluation may provide answers to the following main questions:

- What strategies are adopted?

- How are the adaptive co-management and design strategies performing?

- What bottlenecks are preventing the full compliance of the adaptive co-management and design strategies?

- What aspects of the case study may be considered as a planning innovation? 


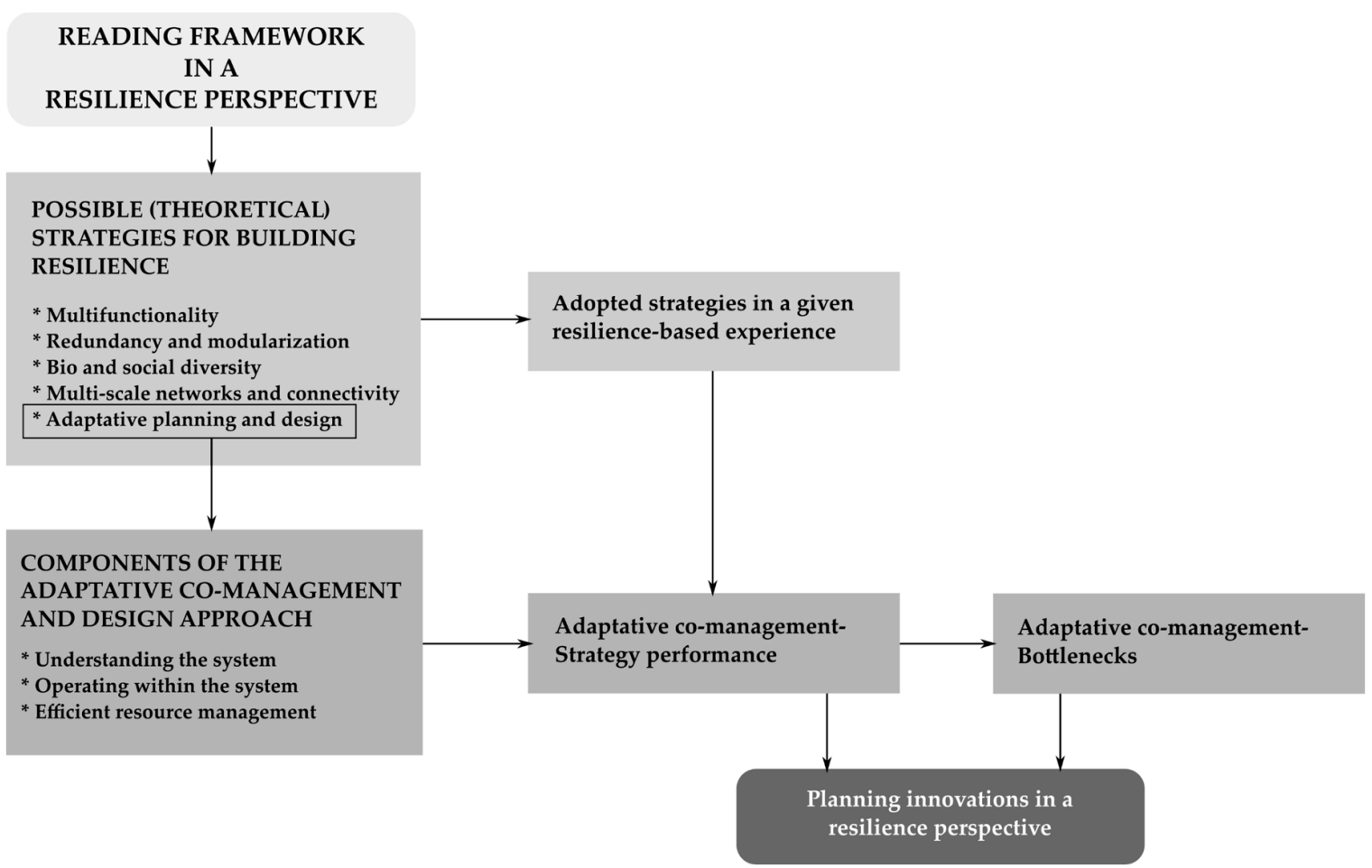

Figure 4. Method workflow. Source: Authors.

\section{Results}

The application of the previous method provides a comprehensive reading of the Charca de Suárez case study. The main objective of this reading is to show a general overview of the strategies for building urban resilience that is implemented in the Charca.

1. Multifunctionality. The role of wetlands has been widely studied in terms of the provision of diverse ecosystem services. With specific reference to the Charca, some works highlight the high multifunctionality of the agro-urban landscape where the Charca is located (see References $[36,40]$ ); and how the own Charca contributes to the eco-structure of the area [41].

2. Redundancy and modularization. In a context of extensive urbanization of coastal areas in Andalucía and especially along with the Coast of Granada, the Charca project, that rejects the possibility of urbanizing one of the last residual open areas, contributes to avoiding putting "all the eggs in one basket". This strategy is also adopted inside the Charca project itself. The acknowledgement of the project as an experiment of continuous learning is the main argument behind the creation of three ponds in the area. Not all the experiential management tasks are undertaken simultaneously in the three ponds, but just in one of them that acts as an experimental pond, while the other two remain as control ponds.

3. Bio and social diversity. The Charca is an example of biodiversity hotspot at the regional and national level. Biological diversity is fostered in the area through the recreation of different habitats that have been successful in attracting new and previously disappeared species. The Charca also aims at increasing social diversity; this objective has been specifically targeted through social inclusion programs to foster participation and accessibility.

4. Multi-scale networks and connectivity. The Charca contributes to the overall physical and biological connectivity of the landscape. Due to its location, the Charca connects agricultural areas to beach areas and the sea.

5. Adaptive planning and design. The Charca puts in place an adaptive planning and design approach to foster flexible management of natural resources. 
Bearing in mind all these strategies, we may focus now on the adaptive planning and design approach implemented in the Charca, that is characterized by a strong "co-management" dimension as well, and we read it according to the different components of the adaptive co-management and design strategical framework as defined by Crowe et al. [21] (hereafter the related key aspects presented in the Charca case study are marked in italics).

\subsection{Understanding the System (Active Observation, Accessible Information, Identification of Drivers of Change, and Broader Value Systems)}

One of the main efforts of the project (especially when the Charca was drained) was to understand the functioning of the system, both ecologically and in the context of its territorial planning. The knowledge and continuous learning from the Charca project are undertaken through active observation organized within the frame of specific research projects set in collaboration with universities: Fauna and flora monitoring; the influence of dams on the hydrodynamics and hydro-chemistry of the aquifer that feeds the wetland; monitoring of water quality and climate factors. Moreover, the follow-up commission undertakes a periodical evaluation of all the activities developed in the Charca, including scholar and volunteering activities linked to the urban-territorial context to which the Charca belongs.

The results and updating of this active and collaborative observation have provided the identification of the main drivers of change. A generic classification of wetland drivers may be found in Gitay et al. [42], who differentiate between direct and indirect drivers. In the Charca project, the main direct drivers are linked to changes in local land use and land cover affecting the surrounding area of the Charca. The wetland itself is not expected to be modified at least in the short to medium term, since it has been protected as NCR. However, the changes in the surrounding area (industrial, agricultural and port areas) are considered to increase the wetland vulnerability. Another direct driver is the irrigation infrastructure change in the agricultural delta, which may be transformed from traditional ditches (acequias) to more artificial systems, then modifying the water entrance to the wetland. Among the indirect drivers, the socio-political ones are of importance. Today, there is a proposal to include the Charca in the Natura 2000 Network, which may have a further impact on the project concerning its national and international visibility, funding possibilities, etc. The economic drivers have also been identified. The territorial model of the area where the Charca is located has moved from a traditional agricultural-based model operating until the 1990s, to an intensive agricultural-based model (especially based on greenhouses) until the first years of 2000 [37]. Then, an urban development-based model has especially affected the area until the housing crisis [43]. Currently, the paralysation of many urban development projects has even led to a re-cultivation of abandoned agricultural lands. The area is now in a crucial moment for the re-definition of its territorial model.

Any action undertaken to understand the system implies the need for accessible information. Currently, there is a great quantity of information directly and indirectly linked to the Charca experience. However, the information appears scattered and has to be specifically demanded, since it has not been systematically organized and presented, e.g., through the website or other system granting accessibility.

All the previous key aspects contribute to broadening the value system by making possible to acknowledge the complex values of both the Charca and the surrounding Delta del Guadalfeo, from an ecological, cultural, social and economic point of view.

\subsection{Operating within the System (Less-hierarchical Approach; Collaborative and Supportive Networks; Build Community Capital; Incremental and Experimental Approach)}

Since its origin, the project aimed at gathering different stakeholders in a supportive network, to collaborate to restore and manage the Charca (see Figure 5). This effort has implied a less-hierarchical approach of the project compared to other cases of Protected Area management. The collaborative and supportive network of the Charca project (Figure 4) works at two main levels: 
(a) Local level: Three of the six members of the follow-up commission work at the local level organizing the collaborative and supportive network in the area. This part of the network is mainly composed of local people who organize around the open annual volunteering program that is coordinated by the environmental association Buxus and the Local Council of Motril. The network also includes schools and secondary schools that develop specific environmental education activities. Tourism boards both at the local and sub-regional level are also present. The University of Granada plays an important role, by offering direct advice and receiving information from other components of the network that is included in research projects of varied nature.

(b) Regional and national levels: The other three members of the follow-up commission are nodes that connect the project at regional and national levels. This part of the network moves on the spheres of regional spatial planning and regional-national nature conservation. The Charca is included as an Environmental Protection Zone in the Sub-regional Plan of the Costa Tropical de Granada. It is also part of the RENPA (Andalusian Network of Protected Natural Spaces) and has been included in the Spanish Inventory of Wetlands. The network at regional and national levels includes universities from other parts of the Andalusian region together with the Spanish National Research Council (CSIC). These institutions are developing monitoring projects, especially concerning fauna and flora of the wetland.

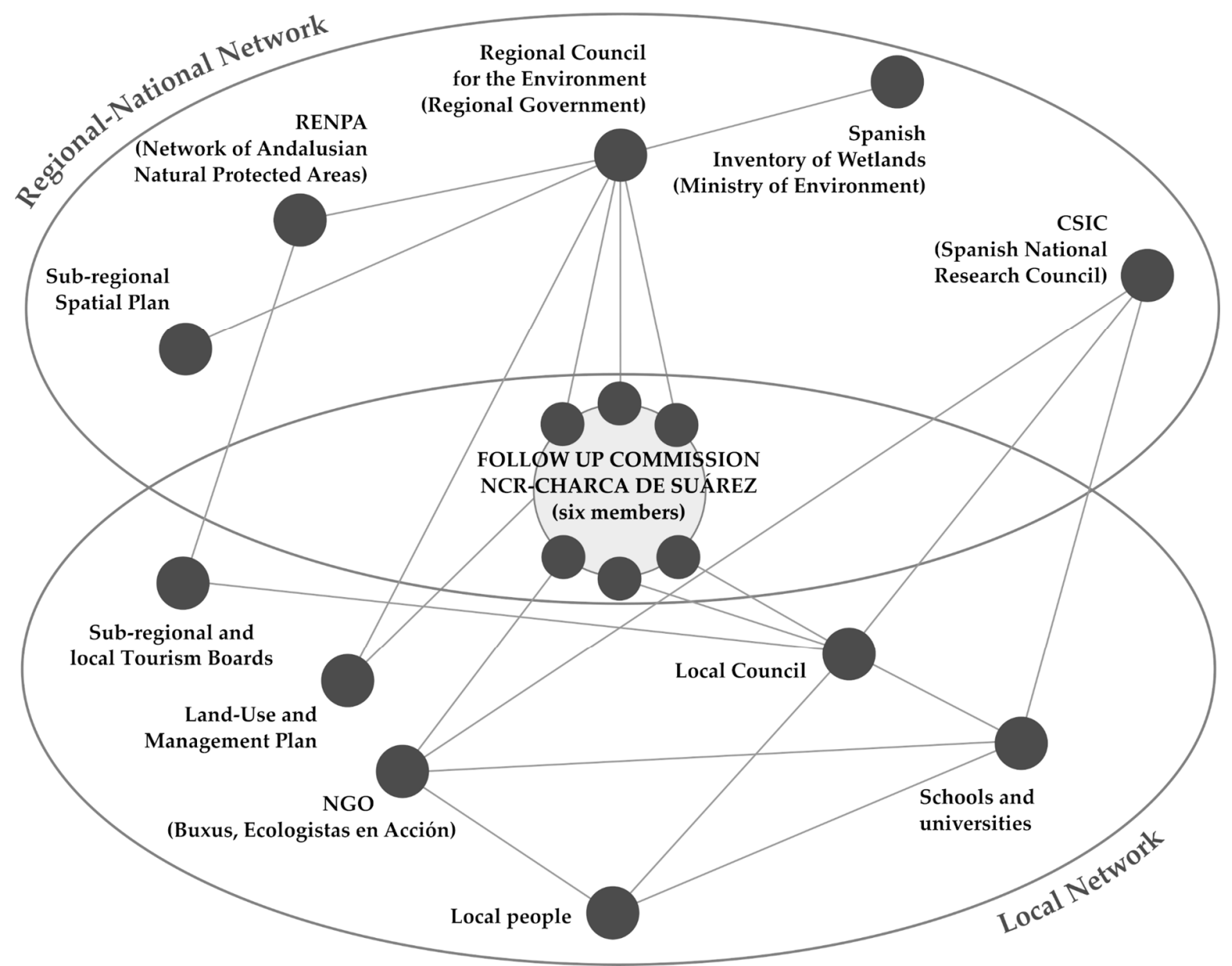

Figure 5. The collaborative and supportive network of the Charca de Suárez (actors and tools). Source: Authors.

Concerning the community capital, Table 1 includes the main facts that acknowledge the building of different community capitals, as defined by Flora et al. [44]. 
Table 1. Community capitals built through the Charca experience.

\begin{tabular}{|c|c|}
\hline Community Capitals & Contribution of the Charca \\
\hline Natural & $\begin{array}{l}\text { The project has entailed the recovering of a wetland area that constitutes one of the } \\
\text { most important ecological nodes at local, sub-regional and even regional level. } \\
\text { Furthermore, the area is protected as Nature Concerted Reserve. It also constitutes an } \\
\text { "environmental facility" according to the interpretation of the Spanish Constitution. }\end{array}$ \\
\hline Cultural & $\begin{array}{l}\text { The project represents the cultural expression of the community regarding its local } \\
\text { landscape; the Charca constitutes one of the last redoubts of sugar cane in Europe. }\end{array}$ \\
\hline Political & $\begin{array}{c}\text { The project has allowed the community to fully participate in the area protection, } \\
\text { design and management. }\end{array}$ \\
\hline Social & $\begin{array}{l}\text { Networking is a principal component of the Charca experience, not just through the } \\
\text { formal network that the Follow-up Commission entails, but also through the extended } \\
\text { network, including other organizations, institutions and individuals. }\end{array}$ \\
\hline Financial or economic & $\begin{array}{l}\text { The area was acquired by the Local Council, making the Charca a municipal property. } \\
\text { Besides, being protected as Nature Concerted Reserve, the Charca may participate in } \\
\text { funding calls for promoting conservation and public use of Protected Areas. }\end{array}$ \\
\hline Physical or built capital & $\begin{array}{l}\text { The Charca is considered as an environmental facility and as a green-blue } \\
\text { infrastructure. Bird hides and a nature classroom have been built in the Charca. }\end{array}$ \\
\hline Human capital & $\begin{array}{l}\text { The close implication of primary and secondary schools through environmental } \\
\text { educational activities is contributing to increasing collective knowledge and awareness } \\
\text { about different topics related to the planning and management of the Charca. } \\
\text { Some students are later becoming volunteers for managing the area. }\end{array}$ \\
\hline
\end{tabular}

Source: Authors.

The incremental and experimental approach [45] is also present in the planning process of the Charca. Continuous feedback and short-term objectives allow an incremental updating of the planning process, compatible with a long-term vision of the project.

\subsection{Efficient Resource Management (Build Local Awareness; Connect Resources, People, and Places; Use What Exists Optimally; Design for Change)}

Specific social awareness campaigns were conducted, especially at the beginning of the project, to build local awareness. In the late 90s, the belief that wetlands were the focus of insalubrity remained in some part of the population, and this idea was used by some actors (construction companies in particular) trying to stop the restoration and protection project of the Charca. Insalubrity reasons were the drivers to promote drying and transformation in other Spanish wetlands. The success of the local awareness building had its reflection in the great social pressure that finally led to the change in the local urban planning and the decision of acquiring the land by the Local Council to develop the project.

This local awareness is the crucial key to connect resources, people and places within the context of the Charca. People have connected to this space through an appropriation process that was informal in the first stages (before the Declaration of the NCR), and then formally conducted, including resource allocation for the project and its recognition at the regional level.

There has also been quite an optimal use of existing resources. That is related to the fact of taking advantage of the existing community capital. Two main examples of this optimal use may be cited. One is the effective use of the human, political and physical capital of the local environmental association Buxus. Instead of building a specific entity for the project, the project itself widely relay on the existing capacity of Buxus, which was founded in 1994 and accumulate both, local and scientific knowledge on many topics affecting the Coast of Granada, the Delta del Guadalfeo, and particularly, the Charca de Suárez. The other example is the use of scientific and academic material provided by the University of Granada. Buxus and Follow up Commission members have undertaken a continuous review and discussion of these materials to find explanations and solutions to different processes, directly and indirectly, affecting the Charca. 
Finally, the Charca constitutes a practical example of how to design for change. In particular, there has been a significant change in the local knowledge about wetlands, which have been traditionally seen only as insalubrious areas.

\section{Discussion}

As introduced in the method sections, some discussion points arise concerning the level of achievement of the strategies and the aspects of adaptive co-management and design:

- What strategies are adopted?

- How are the adaptive co-management strategies performing?

- What bottlenecks are preventing the full compliance of the adaptive co-management and design approach?

- What aspects of the case study may be considered a planning innovation?

\subsection{What Strategies are Adopted?}

According to our results, the Charca de Suárez has adopted all of the strategies for urban resilience identified by Ahern. However, the first and main strategy adopted in the Charca was certainly related to bio and social diversity. Even before its protection as NCR and the implementation of the Management Plan and the Follow-up Commission, the first steps are undertaken were to restore and promote the biological diversity in the Charca and parallelly to reach as much as social diversity of actors as possible as a way to foster successful engagement and dialogue. To this aim, an important complementary strategy was that of adaptive co-management.

\subsection{How are the Adaptive Co-Management Strategies Performing?}

This question may be globally discussed through the different components of the adaptive co-management and design met by a given project. We assume that the more components a strategy meets, the more likely to succeed. Our analysis showed that our study case fulfils the overall key aspects provided by Crowe et al. Even so, we think that three key aspects, in particular, emerge in the Charca project: (1) The less hierarchical approach; (2) the collaborative and supportive network; and (3) the community capital built through the project. The less-hierarchical approach is crucial to resilience, since local formal competencies are expected to better cope with unexpected changes by providing local responses [46]. On the other hand, a less hierarchical approach implies the delegation of regulatory authority, which is something difficult to achieve, as stated by Hettiarachchi et al. [33]. A less hierarchical approach is also possible if learning permeates at all levels acting as a catalyst for the collaborative and supportive network. In their analysis of lake and wetland social-ecological systems from USA and Sweden, Gunderson et al. [47] conclude that learning is a key ingredient and is facilitated through networks that operate in distinct arenas, as it is the case of the Charca network. Through the analysis of our study case, we have verified that continuous learning is basic to build community capitals. Furthermore, this learning is experiential and is gathered among all community members involved contributing to improving the science of urban wetlands, especially through the collaboration between higher education and urban development [48]. As we have seen throughout the present work, the University of Granada and the National Research Council are part of the collaborative and supportive network of the Charca.

\subsection{What Bottlenecks are Preventing the Full Compliance of the Adaptive Co-Management and Design Approach?}

The main weakness of the project derives from the difficulty to access information which relates to the project itself. The difficulty of accessing information can impact on the full compliance of the adaptive co-management. If the information that is produced in the project is not fully and continuously available, this could lead to losing the opportunity to capitalise and implement such information for new activities or future tasks in the Charca. This lack of information also explains why a project like 
the Charca, which has been awarded up to 11 times at the national and international level since 2006, has not been presented before in the scientific literature and in a detailed way as a successful study case. The reason behind this difficulty of accessing information seems to be the scarce economic resources allocated to the project.

\subsection{What Aspects of the Case Study May be Considered a Planning Innovation?}

Planning innovations are attempts to make changes to status quo practices and situations [49]. Broadly speaking, to innovate means "set something new" [25]. The resilience and adaptive co-management and design approaches applied to urban planning are themselves considered as innovations. Still, there is a need to reflect on "how new is new". To discuss this question, we need to recall that the Spanish Planning System is considered to perform more like a blueprinting policy than as a continuous learning-process [50]. Within the general context of the resilience paradigm, it can be a disadvantage or even an obstacle. This is a fact whose extensive reflection is not the aim of the present work (it has not been discussed either in the Spanish planning literature yet), but serves as a starting point to understand up to which point the Charca de Suárez project also constitutes a planning innovation.

As commented in the previous sections, the Charca entailed a change in the way urban planning usually performs, since reclassification of urban and developable land to non-developable land is especially infrequent in Spanish planning. Besides, the consideration of the Charca as an "environmental facility" has implied a novel interpretation of the Spanish Constitution, making effective the right to an adequate environment (Art. 45).

The Charca is also a very specific case of Nature Concerted Reserve. Five of them currently exist in Andalucía, but just the Charca presents the particular key aspects to be considered as an adaptive co-management and design experience. In part, it has to do with the fact that the Management Plan and the Follow-up Commission were not mandatory instruments for the specific case of the Charca (considering the local urban and environmental regulations), but intentionally brought to the scene to assure an adaptive and participated management. Recent works [51,52] propose the creation of conservation committees as instruments to govern wetlands. In a context in which little consolidated information is available on how urban wetlands are governed [33], the Charca study case has provided information on how its governing is undertaken. In other Spanish wetland cases, as in some Valencian wetlands, the instrument adopted was a Special Plan, that is an urban planning tool that regulates uses and activities from a sectoral perspective. According to Sebastià-Frasquet et al. [29], this instrument generally fails, due to two main reasons: Its limited scope (extremely local) and the diversity of purposes depending on the various interests of the local authority. We assume that the success of the Charca mainly relays on its previously commented less hierarchical approach and the possibility of setting a collaborative and supportive network. Those are more difficult goals to achieve through a Special Plan, where local authorities tend to retain power.

\section{Conclusions}

The reading of the Charca experience presented in this article has pursued two main objectives. Firstly, it has provided a theoretical framework to read, understand and evaluate resilience-based projects. We think this analytical and assessment framework, based on the cross-referenced reading of References [3,21,39], could be successfully transferred also to other projects aimed at urban resilience. The steps to be followed are clear; from the identification of the specific resilience strategies to the understanding of how they perform considering, in particular, the adaptive co-management components and key aspects. However, there are also some limitations in the framework we propose, mainly consisting of the need to gather data/information of very different nature in order to fulfil the framework of analysis. This information may not be easy to collect. 
Secondly, the reading of the Charca experience has contributed to filling in the gap on the operationalization of urban resilience at the local planning level, by presenting a case study that can be acknowledged as an innovative planning practice, a source of inspiration for visions and experiments oriented to urban resilience.

However, despite the fact that until today the Charca case proved to be a successful example of local planning oriented towards resilience, we should be mindful that several threats could undermine the project's effectiveness in the short, medium and long term:

- In the short term: Light and sound pollution of urbanizations, the arrival of exotic garden plants, the pressure of exotic fauna, domestic fauna (especially cats and feral dogs), water pollution from uncontrolled dumping of the adjacent industrial area, contaminated water entering during the rains, and lack of budget allocation.

- In the medium term: Urban development, especially the proposal for the construction of a marina that would induce the entry of brackish water near the Charca and may cause a decrease in piezometric levels. That would also isolate the Charca area to the west. A proposal for piping the traditional irrigation ditches, which will reduce the contributions to the aquifer (by more than a third) and make disappear hundreds of water channels that constitute the connection routes of the wetland with its environment.

- In the long term: Climate change. Climate change scenarios provided by the Andalusian Regional Council for the Environment indicate an increase in the sea level that will have at least two effects: Salt wedge advance and beach erosion. Changes in evapotranspiration, water availability and the arrival of exotic plants and fauna may also occur.

All these threats will test in the future the actual effectiveness of the Charca policies. Some of these threats-especially those in the short and medium-term-are currently being debated, so we think that this study could also help to provide new insights and arguments for decision-makers. However, the current study should be complemented by further investigation to monitor over time the above-mentioned threats, assess their impact on the Charca landscape and adapt the Charca planning and management policies in the face of future challenges.

Author Contributions: Conceptualization, E.S. and R.P.-C.; methodology, E.S. and R.P.-C.; data curation: F.A.-R., R.P.-C. and R.T.-G.; investigation: E.S. and F.A.-R.; visualization: R.T.-G.; writing一original draft: E.S. and R.P.-C. All authors discussed and agreed to submit the manuscript. All authors have read and agreed to the published version of the manuscript.

Funding: This research received no external funding.

Acknowledgments: We thank all people involved in the Charca de Suárez. They have been an example for us and have actively collaborated to make this research possible. R.T. thanks to the Spanish Government for the Juan de la Cierva fellowship (Ref FJCI-2017-31662).

Conflicts of Interest: The authors declare no conflict of interest.

\section{References}

1. Meerow, S.; Newell, J.P.; Stults, M. Defining urban resilience: A review. Landsc. Urban Plan. 2016, 147, 38-49. [CrossRef]

2. Chandler, D.; Coaffee, J. The Routledge Handbook of International Resilience; Routledge: Abingdon, UK, 2016.

3. Pizzo, B. Problematizing resilience: Implications for planning theory and practice. Cities 2015, 43, $133-140$. [CrossRef]

4. Ahern, J. From fail-safe to safe-to-fail: Sustainability and resilience in the new urban world. Landsc. Urban Plan. 2011, 100, 341-343. [CrossRef]

5. Botkin, D.B. Discordant Harmonies: A New Ecology for the Twenty-first Century; Oxford University Press: New York, NY, USA, 1990. 
6. Pickett, S.T.A.; Cadenasso, M.L.; Grove, J.M. Resilient cities: Meaning, models, and metaphor for integrating the ecological, socio-economic, and planning realms. Landsc. Urban Plan. 2004, 69, 369-384. [CrossRef]

7. Walker, B.H.; Salt, D. Resilience Thinking: Sustaining Ecosystems and People in a Changing World, 1st ed.; Island Press: Washington, DC, USA, 2006.

8. Plieninger, T.; Bieling, C. Resilience and the Cultural Landscape: Understanding and Managing Change in Human-shaped Environments; Cambridge University Press: Cambridge, UK, 2012.

9. Ahern, J. Planning for Resilient and Sustainable Cities. In Water Centric Sustainable Communities: Planning, Retrofitting, and Building the Next Urban Environment; John Wiley \& Sons: Hoboken, NJ, USA, 2010; pp. $539-593$.

10. Davoudi, S.; Shaw, K.; Haider, L.J.; Quinlan, A.E.; Peterson, G.D.; Wilkinson, C.; Fünfgeld, H.; McEvoy, D.; Porter, L.; Davoudi, S. Resilience: A Bridging Concept or a Dead End? "Reframing" Resilience: Challenges for Planning Theory and Practice Interacting Traps: Resilience Assessment of a Pasture Management System in Northern Afghanistan Urban Resilience: What Does it Mean in Planning Practice? Resilience as a Useful Concept for Climate Change Adaptation? The Politics of Resilience for Planning: A Cautionary Note: Edited by Simin Davoudi and Libby Porter. Plan. Theory Pract. 2012, 13, 299-333.

11. Collier, M.J.; Nedović-Budić, Z.; Aerts, J.; Connop, S.; Foley, D.; Foley, K.; Newport, D.; McQuaid, S.; Slaev, A.; Verburg, P. Transitioning to resilience and sustainability in urban communities. Cities 2013, 32, S21-S28. [CrossRef]

12. Davoudi, S.; Brooks, E.; Mehmood, A. Evolutionary Resilience and Strategies for Climate Adaptation. Plan. Pract. Res. 2013, 28, 307-322. [CrossRef]

13. Plummer, R.; Baird, J. Adaptive Co-Management for Climate Change Adaptation: Considerations for the Barents Region. Sustainability 2013, 5, 629-642. [CrossRef]

14. Wilkinson, C. Social-ecological resilience: Insights and issues for planning theory. Plan. Theory 2012, 11, 148-169. [CrossRef]

15. Plummer, R.; Crona, B.; Armitage, D.R.; Olsson, P.; Tengö, M.; Yudina, O. Adaptive Comanagement: A Systematic Review and Analysis. Ecol. Soc. 2012, 17, 21. [CrossRef]

16. Chapman, S.; Sullivan, C.; Palm, C.; Huynh, U.; Diru, W.; Masira, J. Monitoring and evaluation to support adaptive co-management: Lessons learned from the Millennium Villages Project. J. Environ. Manag. 2016, 183, 142-151. [CrossRef] [PubMed]

17. Ludwig, D. The Era of Management Is Over. Ecosystems 2001, 4, 758-764. [CrossRef]

18. Ghofrani, Z.; Sposito, V.; Faggian, R. Maximising the Value of Natural Capital in a Changing Climate Through the Integration of Blue-Green Infrastructure. J. Sustain. Dev. Energy Water Environ. Syst. 2020, 8, 213-234. [CrossRef]

19. Bush, J.; Doyon, A. Building urban resilience with nature-based solutions: How can urban planning contribute? Cities 2019, 95, 102483. [CrossRef]

20. Abson, D.J.; von Wehrden, H.; Baumgärtner, S.; Fischer, J.; Hanspach, J.; Härdtle, W.; Heinrichs, H.; Klein, A.M.; Lang, D.J.; Martens, P.; et al. Ecosystem services as a boundary object for sustainability. Ecol. Econ. 2014, 103, 29-37. [CrossRef]

21. Crowe, P.R.; Foley, K.; Collier, M.J. Operationalizing urban resilience through a framework for adaptive co-management and design: Five experiments in urban planning practice and policy. Environ. Sci. Policy 2016, 62, 112-119. [CrossRef]

22. Walters, C.J.; Holling, C.S. Large-Scale Management Experiments and Learning by Doing. Ecology 1990, 71, 2060-2068. [CrossRef]

23. Coaffee, J.; Therrien, M.-C.; Chelleri, L.; Henstra, D.; Aldrich, D.P.; Mitchell, C.L.; Tsenkova, S.; Rigaud, É.; the participants. Urban resilience implementation: A policy challenge and research agenda for the 21st century. J. Contingencies Crisis Manag. 2018, 26, 403-410. [CrossRef]

24. Ziervogel, G.; Pelling, M.; Cartwright, A.; Chu, E.; Deshpande, T.; Harris, L.; Hyams, K.; Kaunda, J.; Klaus, B.; Michael, K.; et al. Inserting rights and justice into urban resilience: A focus on everyday risk. Environ. Urban. 2017, 29, 123-138. [CrossRef]

25. Friedmann, J. Toward a Non-Euclidian Mode of Planning. J. Am. Plan. Assoc. 1993, 59, 482-485. [CrossRef]

26. Kato, S.; Ahern, J. 'Learning by doing': Adaptive planning as a strategy to address uncertainty in planning. J. Environ. Plan. Manag. 2008, 51, 543-559. [CrossRef] 
27. Darchen, S.; Searle, G. Seoul, South Korea: Dismantling a highway-Cheonggyecheon Restoration Project. In Global Planning Innovations for Urban Sustainability; Routledge: Abingdon, UK, 2018; pp. 137-150.

28. Manuel, P.M. Cultural perceptions of small urban wetlands: Cases from the Halifax Regional Municipality, Nova Scotia, Canada. Wetlands 2003, 23, 921-940. [CrossRef]

29. Sebastiá-Frasquet, M.-T.; Altur, V.; Sanchis, J.-A. Wetland Planning: Current Problems and Environmental Management Proposals at Supra-Municipal Scale (Spanish Mediterranean Coast). Water 2014, 6, 620-641. [CrossRef]

30. Wardekker, J.A.; Wildschut, D.; Stemberger, S.; van der Sluijs, J.P. Screening regional management options for their impact on climate resilience: An approach and case study in the Venen-Vechtstreek wetlands in the Netherlands. SpringerPlus 2016, 5, 750. [CrossRef]

31. Ehrhart, S.; Schraml, U. Adaptive co-management of conservation conflicts-An interactional experiment in the context of German national parks. Heliyon 2018, 4, e00890. [CrossRef]

32. Ehrenfeld, J.G. Evaluating wetlands within an urban context. Urban Ecosyst. 2000, 4, 69-85. [CrossRef]

33. Hettiarachchi, M.; McALPINE, C.; Morrison, T.H. Governing the urban wetlands: A multiple case-study of policy, institutions and reference points. Environ. Conserv. 2014, 41, 276-289. [CrossRef]

34. Ward, J.D. Can urban agriculture usefully improve food resilience? Insights from a linear programming approach. J. Environ. Stud. Sci. 2015, 5, 699-711. [CrossRef]

35. Frontana, J. El clima de la Costa del Sol de Granada. Aplicaciones Socio-económicas; Universidad de Granada: Granada, Spain, 1984.

36. Pérez-Campaña, R.; Valenzuela-Montes, L.M. Agro-urban open space as a component of agricultural multifunctionality. J. Land Use Sci. 2014, 9, 82-104. [CrossRef]

37. Matarán-Ruiz, A. La Valoración Ambiental-territorial de las Agriculturas de Regadío en el Litoral Mediterráneo: El Caso de Granada; Universidad de Granada: Granada, Spain, 2005.

38. Olsson, P.; Folke, C.; Hahn, T. Social-Ecological Transformation for Ecosystem Management: The Development of Adaptive Co-management of a Wetland Landscape in Southern Sweden. Ecol. Soc. 2004, 9, art2. [CrossRef]

39. Ahern, J. Urban landscape sustainability and resilience: The promise and challenges of integrating ecology with urban planning and design. Landsc. Ecol. 2013, 28, 1203-1212. [CrossRef]

40. Valenzuela Montes, L.M.; Pérez Campaña, R. Ecoestructura y Multifuncionalidad del Paisaje Agrourbano. Ediciones Universidad de Valladolid 2009, 12, 67-95. [CrossRef]

41. Pérez-Campaña, R.; Valenzuela-Montes, L.M. Nodes of a peri-urban agricultural landscape at local level: An interpretation of their contribution to the eco-structure. J. Environ. Plan. Manag. 2018, 61, 406-429. [CrossRef]

42. Gitay, H.; Finlayson, C.M.; Davidson, N. A Framework for Assessing the Vulnerability of Wetlands to Climate Change; Ramsar Convention Secretariat: Gland, Switzerland, 2011.

43. Pérez-Campaña, R. La vega del Guadalfeo Como Paisaje Agrario Periurbano. Transformación, Ecoestructura y Multifuncionalidad; Universidad de Granada: Granada, Spain, 2013; Available online: http://purl.org/dc/ dcmitype/Text (accessed on 3 June 2019).

44. Flora, C.B. Rural Communities: Legacy and Change; Westview Press: Boulder, CO, USA, 2016; ISBN 978-0-8133-4971-8.

45. Evans, J.; Karvonen, A.; Raven, R. The Experimental City; Routledge: Abingdon, UK, 2016; ISBN 978-1-317-51715-3.

46. Wardekker, J.A.; de Jong, A.; Knoop, J.M.; van der Sluijs, J.P. Operationalising a resilience approach to adapting an urban delta to uncertain climate changes. Technol. Forecast. Soc. Chang. 2010, 77, 987-998. [CrossRef]

47. Gunderson, L.H.; Carpenter, S.R.; Folke, C.; Olsson, P.; Peterson, G. Water RATs (Resilience, Adaptability, and Transformability) in Lake and Wetland Social-Ecological Systems. Ecol. Soc. 2006, 11, art16. [CrossRef]

48. Ahn, C.; Schmidt, S. Designing Wetlands as an Essential Infrastructural Element for Urban Development in the era of Climate Change. Sustainability 2019, 11, 1920. [CrossRef]

49. Bai, X.; Roberts, B.; Chen, J. Urban sustainability experiments in Asia: Patterns and pathways. Environ. Sci. Policy 2010, 13, 312-325. [CrossRef] 
50. Soria-Lara, J.A.; Zúñiga-Antón, M.; Pérez-Campaña, R. European spatial planning observatories and maps: Merely spatial databases or also effective tools for planning? Environ. Plann B Plann Des. 2015, 42, 904-929. [CrossRef]

51. Roy-Basu, A.; Bharat, G.K.; Chakraborty, P.; Sarkar, S.K. Adaptive co-management model for the East Kolkata wetlands: A sustainable solution to manage the rapid ecological transformation of a peri-urban landscape. Sci. Total Environ. 2020, 698, 134203. [CrossRef]

52. WWT Consulting. Good Practices Handbook for Integrating Urban Development and Wetland Conservation; Wildfowl \& Wetlands Trust: Slimbridge, UK, 2018.

(C) 2020 by the authors. Licensee MDPI, Basel, Switzerland. This article is an open access article distributed under the terms and conditions of the Creative Commons Attribution (CC BY) license (http://creativecommons.org/licenses/by/4.0/). 